ISSN 0103-5150

Fisioter. Mov., Curitiba, v. 26, n. 3, p. 631-638, jul./set. 2013

Licenciado sob uma Licença Creative Commons

\title{
Translation and cross-cultural adaptation of the Duke Activity Status Index to Brazilian Portuguese
}

\author{
Tradução e adaptação cultural do Duke Activity \\ Status Index para a língua portuguesa
}

\section{Laura Maria Tomazi Neves ${ }^{[a]}$, Alberto Klohn Neto ${ }^{[b]}$, Fernanda Pasquale Arenas ${ }^{[b]}$, Luis Vicente Franco de Oliveira ${ }^{[\mathrm{cl}}$, Ross Arena ${ }^{[\mathrm{d}]}$, Gerson Cipriano Junior ${ }^{[\mathrm{e}]}$}

[a] Master's degree, Doctoral student, Postgraduate Program in Health Sciences and Technology, Brasília University (UnB), Brasília, DF - Brazil, e-mail: lmtomazi@gmail.com

[b] Specialists, Sector of Cardiovascular Surgery, Federal University of São Paulo (Unifesp), São Paulo, SP - Brazil, e-mails: albertoklohnft@hotmail.com, fernanda.arenas@yahoo.com.br

[c] Doctoral degree, Teaching staff member, Postgraduate Program in Rehabilitation Sciences, Nove de Julho University (Uninove), São Paulo, SP - Brazil, e-mail: oliveira.lvf@pq.cnpq.br

[d] Doctoral degree, Teaching staff member, Department of Physical Therapy, College of Applied Health Sciences, University of Illinois Chicago, Chicago, IL - USA, e-mail: rarena70@gmail.com

[e] Doctoral degree, Post-graduate Program in Physical Education; Postgraduate Program in Health Sciences and Technology, Teaching staff member in Physical Therapy Course, Brasília University (UnB), Brasília, DF - Brazil, e-mail: cipriano@unb.br

\begin{abstract}
Introduction: The limited number of valid and reliable questionnaires for the evaluation of exercise tolerance has stimulated the development of simple international assessment tools for this purpose, one of the most widely used of which is the Duke Activity Status Index (DASI). However, this index has not yet been translated and adapted to the Portuguese language. Objective: To develop a Brazilian version of the DASI and cross-culturally adapt it for the evaluation of cardiorespiratory fitness among patients with cardiovascular disease in Brazil. Materials and methods: The translation process involved four stages: initial translation, back-translation, multidisciplinary committee review and pre-test with 16 subjects ( 8 cardiac patients and 8 healthy individuals). Patients were screened from outpatient Cardiac Surgery, São Paulo Hospital. The Mann-Whitney and chi-square tests were employed to determine differences between controls and individuals with heart disease. Results: The sample was characterized by individuals aged $\geq 50$ years who were mainly from the southeastern region of Brazil (62.5\%)
\end{abstract}


and were non-smokers (56.2\%). Less than half of the cohort was considered physically active (43.75\%). The level of non-understanding was less than $10 \%$ of the sample. Doubts were prevalent among individuals with heart disease (75\%) regarding the level of fatigue caused when performing a task. Conclusions: The present findings demonstrate that the DASI was successfully translated and adapted to Brazilian Portuguese.

Keywords: Translating. Exercise test. Physical fitness.

\section{Resumo}

Introdução: A limitação quanto ao uso rotineiro e em escala populacional dos métodos de maior acurácia para avaliação da capacidade incentivou o desenvolvimento de questionários de estimativa. O questionário Duke Activity Status Index (DASI) é um dos mais utilizados, no entanto ainda não traduzido e adaptado para língua portuguesa. Objetivo: Desenvolver uma versão brasileira do DASI e adaptá-lo culturalmente para avaliação da capacidade cardiorrespiratória de cardiopatas no Brasil. Materiais e métodos: Foram realizadas quatro etapas metodologicamente recomendadas para esta finalidade: tradução inicial, tradução reversa, revisão por comitê multidisciplinar e pré-teste de verificação com 16 indivíduos (oito cardiopatas e oito saudáveis). Os pacientes foram triados no ambulatório da Cirurgia Cardíaca do Hospital São Paulo. Para verificar as possíveis diferenças entre os indivíduos saudáveis e cardiopatas foram utilizados os testes $\alpha$ Mann-Whitney ou qui-quadrado. Resultados: A amostra foi caracterizada por indivíduos procedentes da região Sudeste (62,5\%), não tabagistas (56,2\%), ativos (43,75\%) e com idade $\geq 50$ anos. O nível de não compreensão aceitável foi de até $10 \%$ dos entrevistados. As dúvidas foram predominantes nos cardiopatas (75\%) em relação ao grupo saudável (12,5\%), sendo concentradas na consideração ou não do nível de cansaço para realizar a tarefa. Conclusões: Os resultados demonstram que o DASI foi satisfatoriamente traduzido e adaptado para a lingua portuguesa.

Palavras-chave: Tradução (processo). Teste de esforço. Aptidão física.

\section{Introduction}

The assessment of cardiorespiratory fitness on a population level is important to the establishment of preventive strategies aimed at addressing risk factors, favoring a reduction in cardiovascular disease (1-3). However, specific tests for the evaluation of cardiorespiratory fitness, such as cardiopulmonary exercise testing, have a lower degree of broad applicability due to the high cost, the time required for the evaluation and technical-operational logistics

The development of fast, simple tools for the determination of cardiorespiratory fitness, such as questionnaires and multiple regression equations, is of considerable importance due the favorable cost/benefit ratio and usefulness in epidemiological studies, especially in locations with inadequate infrastructure for advanced exercise testing $(1,4-6)$. Based on these principles, Hlatky et al. (5) created a self-administrated questionnaire denominated the Duke Activity Status Index (DASI) in the United States. This index is employed to predict cardiorespiratory fitness and has been widely used for patients with cardiovascular disease (7-14).
In Brazil, however, there is a lack of tools for this purpose and an eminent need to assess the degree of cardiorespiratory capacity, especially in patients with cardiovascular disease; given it is the third leading cause of death in the country. There is also a need to find assessment tools that are widely employed in the scientific literature and validate such measures for use on patients in Brazil. Thus, the DASI seems to be one of the most adequate options for the Brazilian population. However, this index has not yet been submitted to translation and cross-cultural adaptation to Brazilian Portuguese (15-19).

The present study aims at developing the Brazilian version of the DASI and cross-culturally adapting it for the evaluation of cardiorespiratory fitness among patients with cardiovascular disease in Brazil.

\section{Materials and methods}

This study received approval from the Human Research Ethics Committee of the Federal University of São Paulo (Unifesp), Brazil, under process number 
006/2009 in compliance with Resolution 196/96 of the Brazilian National Board of Health. All participants received information on the objectives of the study and agreed to participate by signing a statement of informed consent. The study was performed in two steps - translation and cross-cultural adaptation.

\section{Participants}

Two qualified Brazilian translators (laypersons in the field of knowledge in question) performed the translation of the DASI into Brazilian Portuguese. A review committee made up of three Brazilian physical therapists performed the content analysis of all steps of the translation process. All three members of the committee were university professors (experts with a Master's or Doctoral degree), with clinical experience in cardiorespiratory fitness and advanced knowledge of the English language. Two native-English speaking translators performed the back-translation of the DASI, both of whom were fluent in Portuguese and laypersons in the field of knowledge in question. The translated questionnaire was administered to a sample composed of middle-aged (44 to 65 years) male and female individuals (8 patients with a diagnosis of heart failure and 8 healthy individuals) for the semantic analysis of the items on the index. Patients were screened from outpatient Cardiac Surgery, São Paulo Hospital. A cardiologist made the heart failure diagnosis, based on clinical evaluation and ejection fraction, evaluated by echocardiogram. Patients were clinically stable at the time of study inclusion. Exclusion criteria were: having undergone surgical procedures in the previous six months, cognitive impairment, illiteracy and any orthopedic or rheumatologic condition.

\section{Questionnaire}

The DASI is composed of 12 items addressing personal care, household activities, sexual activity and recreational activities. The item scores are weighted based on metabolic cost measured in metabolic equivalents (METs). Each item receives a score ranging from 1.75 to 8.00 points in increasing order of METs. Responses of "no" are scored 0. The total score ranges from 0 to 58.2 points, with higher scores denoting greater functional limitation. The sum of the scores of the 12 items is used in the simple regression equation provided by the questionnaire to estimate peak oxygen uptake $\left(\mathrm{VO}_{2 \text { peak }}\right)$ during exercise. In the original study, a strong correlation $(r=0.80)$ was found between the DASI and $\mathrm{VO}_{2 \text { peak }}$ obtained from the cardiopulmonary exercise test (gold standard) (5).

\section{Translation and cross-cultural adaptation}

The translation and cross-cultural adaptation of the DASI followed the procedures proposed for measures developed in other linguistic and socio-cultural contexts based on studies carried out by Guilhermin et al. (15) Guilhermin (16), Reichenheim and Moraes (17), Maher et al. (18) and Beaton et al. (19). Figure 1 displays the flowchart of the translation and adaptation process.

The translation and adaptation process was performed in three steps:

a) Translation

Two duly qualified Brazilian translators fluent in English performed the translation of the DASI into Portuguese, focusing on a conceptual rather than literal translation. The translators received information on the objectives of the study and were instructed to be precise in their use of language. A review committee composed of three Brazilian health professionals with ample knowledge of English, blinded to the objectives of the study and with experience in the translation of questionnaires, evaluated the two translated versions of the DASI for the correction of possible errors that could lead to different results than those originally proposed. This committee then created a synthesis of the index in Portuguese based on the versions of the two translators.

b) Back-translation

The synthesis version was back-translated into English by two duly qualified native Englishspeaking translators in an independent fashion. The translators were not informed of the objectives of the study and had no access to the original version. The back-translated versions were then compared to the original version of the index by the review committee. Version 2 of the DASI in Portuguese was established following consensus among the committee members on each item of the index. 
c) Cross-cultural adaptation

Version 2 was submitted to semantic analysis to determine whether the terms used in the items and paragraphs were clear. Equivalence was determined through an evaluation of the degree of comprehension or possible doubts regarding each item. Since the DASI was designed as a self-administered questionnaire, the target population participated in this stage. For such, Version 2 of the questionnaire was administered to eight patients with heart failure and eight healthy individuals.

During the administration of the questionnaire, the participant and observer remained isolated and the participant read the items. The "face test" was used to evaluate the degree of comprehension and the option "question difficult to understand" was included on each item. After determining the level of semantic understanding of the questionnaire, the participants were asked to read and answer each item to determine whether comprehension of the questionnaire alone allowed the respondent to answer it properly or whether other associated factors were involved. Any questions and suggestions on the part of the respondent were recorded on the back of the questionnaire. Statistical analysis was performed with the SPSS 15 program to determine possible differences between the patients with heart failure and healthy individuals, using either the Mann-Whitney test or chi-square test, as appropriate.

Following the semantic analysis, the review committee analyzed the suggestions of the participants. Items interpreted as difficult to understand by more than $10 \%$ of the sample $(15,16)$ were reevaluated and rewritten by the committee, resulting in Version 3 of the questionnaire. This version was administered to the group of heart failure patients for analysis and suggestions for further changes. The final version of the questionnaire (Table 1) was determined when all items achieved a $90 \%$ approval rate.

\section{Results}

The evaluations of the review committee regarding the translation of the DASI indicated the occurrence

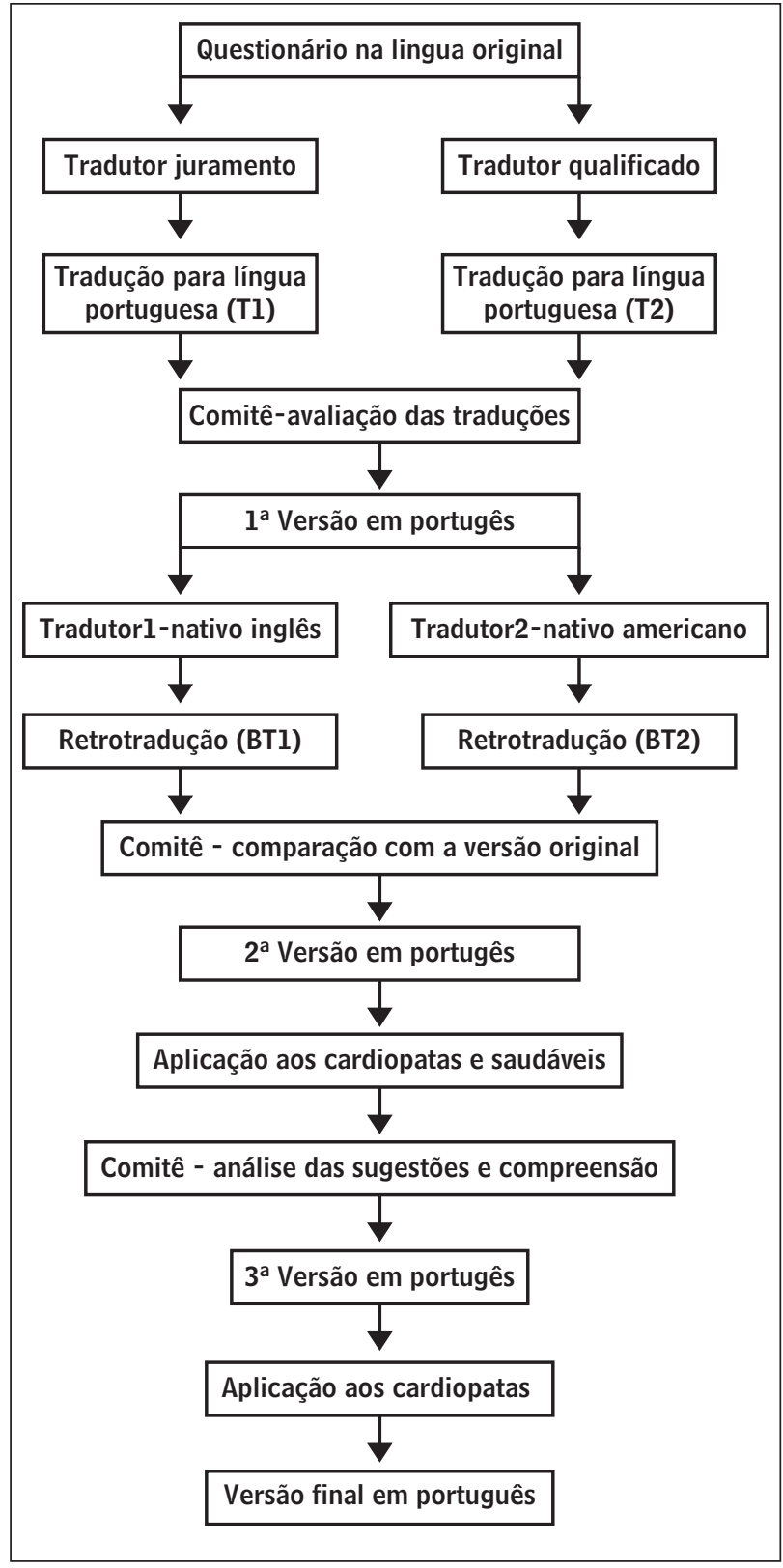

Figure $\mathbf{1}$ - Flowchart of translation and cross-cultural adaptation process of DASI

Source: Research data.

of semantic equivalence with the original questionnaire, but with difficulties on some items. Some activities were replaced with others of similar energy cost that were more suitable to Brazilian culture. The evaluation of the equivalence of the back-translated version to the original questionnaire revealed changes in the grammatical structure of some items. These changes were performed to achieve semantic, idiomatic, experimental and conceptual equivalence of the items (Table 2). 
The sample was characterized by individuals aged $\geq 50$ years who were mainly from the southeastern region of Brazil (62.5\%) and were non-smokers (56.2\%). Less than half of the cohort was considered physically active (43.75\%). Regarding the understanding of the questionnaire, doubts were predominant among individuals with heart failure $(75.0 \%)$ in comparison to the healthy individuals (12.5\%). Items 9 and 11 generated the most doubt. On Item 9 , the individuals questioned the equivalence between "picking up fallen leaves" and "doing yard work". On item 11, the participants questioned the equivalence between "kicking a ball" and "throwing a baseball or football". The patients with heart failure were also unclear as to whether they should take into account the level of fatigue caused when performing a task. The results of the administration of the DASI demonstrated better functional capacity in the healthy individuals. The median time required to fill out the questionnaire was similar between groups (120 seconds among the healthy individuals and 173.5 seconds among the heart failure patients; $p=0.24$ ) (Table 3). The final Brazilian version of the DASI is displayed in Table 1.

\section{Discussion}

The DASI was adequately translated and adapted in accordance with discerning standards for cross-cultural adaptation to Brazilian Portuguese. A number of difficulties were encountered regarding the suitability of activities due to cultural differences. To resolve these issues, repeated changes to some items were required.

Scales and questionnaires designed to assess either general health or a specific disease have been widely employed $(20,21)$. However, many of these assessment tools are not available in Portuguese. The translation and standardization of foreign assessment tools has garnered the interest of a number of Brazilian research groups. This structured process follows a particular sequence of actions $(16,19)$. Indeed, a lack of rigor in the process can lead to biased results and problems, such as the inadequate administration of the measure or incongruence between the original and translated versions, thereby invalidating the use of the measure in other cultures. Moreover, cultural differences should be taken into account to ensure the suitable adaptation of the measure $(20,21)$. In the presentstudy, the choice of cross-culturally

Table 1 - Duke Activity Status Index translated into Brazilian Portuguese

\begin{tabular}{llll}
\hline Item & Atividade & Sim & Não \\
\hline 1 & Você consegue cuidar de si mesmo (comer, vestir-se, tomar banho ou utilizar o vaso sanitário)? & 2,75 & 0 \\
2 & Você consegue andar dentro de casa? & 1,75 & 0 \\
3 & Você consegue andar um ou dois quarteirões em terreno plano? & 2,75 & 0 \\
4 & Você consegue subir uma escada ou uma ladeira? & 5,50 & 0 \\
5 & Você consegue correr uma distância curta? & 8,00 & 0 \\
6 & Você consegue realizar tarefas leves de casa, como tirar o pó ou lavar a louçą? & 2,70 & 0 \\
7 & Você consegue fazer trabalho moderado em casa como aspirar, varrer o chão ou guardar as compras? & 3,50 & 0 \\
8 & Você consegue fazer trabalho pesado em casa, como esfregar o piso ou levantar e movimentar móveis & 8,00 & 0 \\
9 & pesados? & 4,50 & 0 \\
10 & Você consegue realizar tarefas como apanhar folhas caídas ou cortar a grama? & 5,25 & 0 \\
11 & Você consegue ter relações sexuais? & Você consegue participar de atividades de lazer moderadas (boliche, dança, tênis ou chutar uma bola)? & 6,00 \\
12 & Você consegue participar de esportes vigorosos (natação, futebol, basquete ou voleibol)? & 7,50 & 0 \\
\hline Notas: Índice de Atividade de Duke: SOMA (valores de todos os 12 itens); interpretação: valor máximo = 58,2; valor mínimo = $0 ;$ \\
estimativa de pico de oxigênio (em mL/min): 0,43 x (Índice de Atividade de Duke) + 9,6.
\end{tabular}

Source: Hlatky et al. (5).

Note: Duke Activity Status Index is a self-administered questionnaire that measures a patient's functional capacity. It can be used to get a rough estimate of a patient's peak oxygen uptake. 
Table 2 - Summary of translation process of DASI

\begin{tabular}{lll}
\hline Item & Comparative analysis & Joint evaluation \\
\hline Introduction & $\mathrm{T} 1 \neq \mathrm{T} 2$ & $\mathrm{~T} 1$ \\
1 & $\mathrm{~T} 1=\mathrm{T} 2$ & $\mathrm{~T} 1$ or $\mathrm{T} 2$ \\
2 & $\mathrm{~T} 1 \approx \mathrm{T} 2$ & $\mathrm{~T} 2$ \\
3 & $\mathrm{~T} 1 \approx \mathrm{T} 2$ & $\mathrm{~T} 2$ \\
4 & $\mathrm{~T} 1 \approx \mathrm{T} 2$ & $\mathrm{~T} 1$ \\
5 & $\mathrm{~T} 1=\mathrm{T} 2$ & $\mathrm{~T} 1$ or $\mathrm{T} 2$ \\
6 & $\mathrm{~T} 1 \neq \mathrm{T} 2$ & $\mathrm{RV} \rightarrow \mathrm{MV}$ \\
7 & $\mathrm{~T} 1 \neq \mathrm{T} 2$ & $\mathrm{~T} 2$ \\
8 & $\mathrm{~T} 1 \neq \mathrm{T} 2$ & $\mathrm{~T} 2$ \\
9 & $\mathrm{~T} 1 \neq \mathrm{T} 2$ & $\mathrm{RV} \rightarrow \mathrm{MV}$ \\
10 & $\mathrm{~T} 1=\mathrm{T} 2$ & $\mathrm{~T} 1$ or $\mathrm{T} 2$ \\
11 & $\mathrm{~T} 1 \approx \mathrm{T} 2$ & $\mathrm{RV} \rightarrow \mathrm{NV}$ \\
12 & $\mathrm{~T} 1 \approx \mathrm{T} 2$ & $\mathrm{RV} \rightarrow \mathrm{NV}$ \\
Interpretation of scores & $\mathrm{T} 1 \approx \mathrm{T} 2$ & $\mathrm{~T} 1$ \\
\hline
\end{tabular}

Legend: $\mathrm{T} 1=$ translation $1 ; \mathrm{T} 2=$ translation $2 ; \mathrm{T} 1=\mathrm{T} 2=$ versions identical; $\mathrm{T} 1 \approx \mathrm{T} 2=$ versions similar; $\mathrm{T} 1 \neq \mathrm{T} 2=$ versions different; $\mathrm{RV} \rightarrow \mathrm{MV}=$ versions (T1 and T2) rejected by evaluation committee, with modified version based on elements from T1 and T2; VR $\rightarrow \mathrm{NV}=$ rejected version (T1 and T2), with new version established by evaluation committee.

Source: Research data.

Table 3 - Distribution of DASI scores, $\mathrm{VO}_{2 \text { peak }}$ estimated by DASI and time required to fill out questionnaire among healthy individuals and heart patients

\begin{tabular}{lccc}
\hline Variable & $\begin{array}{c}\text { Healthy individuals }(n=8) \\
\mu\left(1^{\text {st }} \text { to } 3^{\text {rd }} \text { quartile }\right)\end{array}$ & $\begin{array}{c}\text { Heart patients }(\mathbf{n}=8) \\
\mu\left(\mathbf{1}^{\text {st }} \text { to } 3^{\text {rd }} \text { quartile }\right)\end{array}$ & $\mathbf{p}$ \\
\hline DASI & $58.2(55.4-58.2)$ & $15.0(10.3-30.3)$ & $0.01^{\dagger}$ \\
$\mathrm{VO}_{2 \text { peak }}(\mathrm{mL} / \mathrm{min})$ & $34.6(33.4-34.6)$ & $16.0(14.0-22.6)$ & $0.01^{\dagger}$ \\
DASI time $(\mathrm{s})$ & $120.0(102.5-150.0)$ & $173.5(111.0-245.0)$ & $0.24^{\dagger}$ \\
\hline
\end{tabular}

Legend: DASI $=$ Duke Activity Status Index; ${ }^{\dagger}=$ Mann-Whitney test.

Source: Research data.

adapting the DASI rather than developing a new questionnaire was based on the possibility of comparing the findings with studies carried out in different countries. Moreover, the development of an original questionnaire is both time consuming and costly (22).

The translation and cross-cultural adaptation of a validated questionnaire is a complex process that goes beyond mere translation due to the need to preserve the semantic and conceptual structure of each item on the original questionnaire and the need to adapt the measure to another culture. The administration of the measure to a sample of the target population assists in the determination of possible errors and ensures the understanding of the measure by individuals with 
different levels of schooling (20). During the translation of the Brazilian version of the DASI back into English, a number of grammatical changes were necessary. These changes made the items more suitable to Brazilian culture in order to achieve semantic equivalence (between words), idiomatic equivalence (between different idiomatic expressions used in the different cultures), experimental equivalence (words adequate to the cultural context) and conceptual equivalence (validity of the concept explored and events experienced by laypersons) $(23,24)$.

Studies have demonstrated that the DASI is correlated with the distance travelled on the Six-Minute Walk Test $(\mathrm{r}=0.53)(10)$, B-type natriuretic peptide levels $(r=0.67)(13)$, the Canadian Cardiovascular Society Classification $(r=0.58)(7)$ and patient quality of life and survival ( $r=0.64)$ (11). Moreover, the questionnaire is sensitive to changes in functional status between the preoperative and postoperative periods of cardiovascular surgery $(8,12)$ and a predictor of the ability to return to work (14). The close-ended questions allow the comparison of results with less variability and facilitate the process of filling out the questionnaire as well as analyzing, coding and transferring the responses to a computer system. However, the use of dichotomous scales on questionnaires addressing functional capacity can lead to imprecise results due to the inherent nuances in this type of evaluation. Thus, the data could be interpreted better using a cumulative scale with a number of response options in an increasing order of intensity for a given characteristic or activity (25). Based on the present findings, the following instructions should be given to respondents prior to filling out the questionnaire: (i) answer YES for any activity that you have been able to perform most days in the previous month without becoming very tired; (ii) answer NO for any activity that you have not performed in the previous month or if you became very tired when performing the activity.

\section{Limitations}

One limitation of the present study resides in the fact that there was no adaptation of the weights of the scores, since such changes would hinder the comparison of the results of Brazilian studies with those carried out in English-speaking countries (25). Moreover, the sample size was small and illiterate individuals were excluded. Thus, further studies involving other groups of patients with cardiovascular disease are needed to determine the validity and reliability of the Brazilian version of the DASI.

\section{Conclusion}

The DASI was satisfactorily translated and crossculturally adapted to Brazilian Portuguese. This index demonstrates adequate psychometric properties for the indirect evaluation of cardiorespiratory fitness in patients with heart failure. The administration of this measure can be accomplished in a short period of time and appears both reliable and valid. Moreover, the use of the DASI in the Brazilian cardiovascular patient population allows for comparison of data across different regions and cultures.

\section{References}

1. Guimarães GV, Bellotti G, Bacal F, Mocelin A, Bocchi EA. Pode o teste ergoespirométrico de caminhada de seis minutos ser representativo das atividades habituais de pacientes com insuficiência cardíaca? Arq Bras Cardiol. 2002;78(6):553-6.

2. Myers J, Zaheer M, Quaglietti S, Madhavan R, Froelicher V, Heidenreich P. Association of functional and health status measures in heart failure. J Card Fail. 2006;12(6):439-45.

3. Taylor HL, Buskirk E, Henschel A. Maximal oxygen intake as objective measure of cardiorespiratory performance. J Appl Physiol. 1955;8:73.

4. Green CP, Porter CB, Bresnahan DR, Spertus JA. Development and evaluation of the Kansas city cardiomyopathy questionnaire: a new health status measure for heart failure. J Am Coll Cardiol. 2000;35(5):1245-55.

5. Hlatky MA, Boineau RE, Higginbotham MB, Lee KL, Mark DB, Califf RM, et al. A brief self-administered questionnaire to determine functional capacity (the Duke Activity Status Index). Am J Cardiol. 1989;64(10):651-4.

6. Olsson LG, Swedberg K, Clark AL, Witte KK, Cleland JGF. Six minute corridor walk test as an outcome measure for the assessment of treatment in randomized, blinded intervention trials of chronic heart failure: a systematic review. Eur Heart J. 2005;26(8):778-93. 
7. Nelson CL, Herdon JE, Mark DB, Pryor DB, Callif RM, Hlatky MA. Relation of clinical and angiographic factors to functional capacity as measured by the Duke Activity Status Index. Am J Cardiol. 1991;68(9):973-5.

8. Alonso J, Permanyer-Miralda G, Cascant P, Brotons C, Prieto L, Soler-Soler J. Measuring functional status of chronic coronary patients. Reliability, validity and responsiveness to clinical change of the reduced version of the Duke Activity Status Index (DASI). Eur Heart J. 1997;18(3):414-9.

9. Arena R, Humphrey R, Peberdy MA. Using the Duke Activity Status Index in heart failure. J Cardiopulm Rehabil. 2002;22(2):93-5.

10. Carter R, Holiday DB, Grothues C, Nwasuruba C, Stocks J, Tiep B. Criterion validity of the Duke Activity Status Index for assessing functional capacity in patients with chronic obstructive pulmonary disease. J Cardiopulm Rehabil. 2002;22(4):298-308.

11. Koch CG, Li L, Lauer M, Sabik J, Starr NJ, Blackstone EH. Effect of functional health-related quality of life on long-term survival after cardiac surgery. Circulation. 2007;115(6):692-9.

12. Koch CG, Li L, Shishehbor M, Nissen S, Sabik J, Starr NJ, et al. Socioeconomic status and comorbidity as predictors of preoperative quality of life in cardiac surgery. J Thorac Cardiovasc Surg. 2008;136(3):665-72.

13. Parissis JT, Nikolaou M, Birmpa D, Farmakis D, Paraskevaidis IA, Bistola V, et al. Clinical and prognostic value of Duke's Activity Status Index along with plasma B-Type natriuretic peptide levels in chronic heart failure secondary to ischemic or idiopathic dilated cardiomyopathy. Am J Cardio. 2009;103(1):73-5.

14. Mark DB, Lam LC, Lee KL, Clap-Channing NE, Williams RB, Pryor DB, et al. Identification of patients with coronary disease at high risk for loss of employment. A prospective validation study. Circulation. 1994;86(5):1485-94.

15. Guillemin F, Bombardier C, Beaton D. Cross-cultural adaptation of health-related quality of life measures: literature review and proposed guidelines. J Clin Epidemiol. 1993;46(12):1417-32.

16. Guillemin F. Cross-cultural adaptation and validation of health status measures. Scand J Rheumatol. 1995;24(2): 61-3.
17. Reichenheim M, Moraes C. Operacionalização de adaptação transcultural de instrumentos de aferição usados em epidemiologia. Rev Saúde Pública. 2007;41(4): 665-73.

18. Maher C, Latmer J, Costa L. The relevance of cross-cultural adaptation and clinimetrics for physical therapy instruments. Rev Bras Fisioter. 2007;11(4): 245-52.

19. Beaton D, Bombardier C, Guillemin F, Ferraz M. Guidelines for process of cross-cultural adaptation of selfreport measures. Spine. 2000;(25)24:3186-91.

20. Paxton EW, Fithian DC, Stone ML, Silva P. The reliability and validity of knee-specific and general health instruments in assessing acute patellar dislocation outcomes. Am J Sports Med. 2003;31(4):487-92.

21. Salaffi F, Carotti M, Grassi W. Health-related quality of life in patients with hip or knee osteoarthritis: comparison of generic and disease-specific instruments. Clin Rheumatol. 2005;24(1):29-37.

22. Tavares MGS, Pizzichini MMM, Steidle LJM, Nazário NO, Rocha CC, Perraro MC, et al. Tradução e adaptação cultural do asthma control scoring system (sistema de escore para controle abrangente da asma) para uso no Brasil. J Bras Pneumol. 2010;36(6):683-92.

23. Victor JF, Ximenes LB, Almeida PC. Cross-cultural adaptation of the exercise benefits/barriers scale (EBBS) for application in elderly Brazilians: preliminary version. Cad Saúde Publica. 2008;24(12):2852-60.

24. Paixão CM Junior, Reichenheim ME, Moraes CL, Coutinho ESF, Veras RP. Adaptação transcultural para o Brasil do instrumento caregiver abuse screen (CASE) para detecção de violência de cuidadores contra idosos. Cad Saúde Publica. 2007;23(9):2013-22.

25. Sardinha A, Nardi AE, Eifert GH. Tradução e adaptação transcultural da versão brasileira do questionário de ansiedade cardíaca. Rev Psiquiatr RS. 2008;30(2):139-49.

Received: 09/30/2012 Recebido: 30/09/2012

Approved: 04/17/2013 Aprovado: 17/04/2013 